\title{
A DYNAMIC PANEL, EMPIRICAL INVESTIGATION ON THE LINK BETWEEN INFLATION AND FISCAL IMBALANCES. DOES HETEROGENEITY MATTER?
}

\author{
Avgeris Nikolaos, Katrakilidis Constantinos*
}

\begin{abstract}
:
This study empirically attempts to unveil the contradictive findings regarding the relationship between fiscal imbalances and inflation in the context of the latest theoretical indications. The empirical analysis covers the period of 1970 to 2009 and applies dynamic panel techniques in a pool of 52 countries that comprises 19 developed and 33 developing ones. This segmentation is applied to illustrate the groups' specific features and the implications of heterogeneity. The findings provide supportive evidence for developing countries. We also find a significant degree of heterogeneity between the groups and the statistical significance of the relationship between fiscal imbalances and inflation in the case of developed countries cannot be ratified.
\end{abstract}

Keywords: fiscal imbalances, inflation, heterogeneity, dynamic panel, GMM

JEL Classification: H62, E31, E42, C23, C52

\section{Introduction}

One ever present topic of furious debate in macroeconomics has been the importance of the public budget balance towards a sustainable growth path. Economics has gone full circle, in the last century, on this topic, from the view of the Austrian school (Ludwig Heinrich von Mises and Friedrich von Hayek) regarding the negative effects of budget deficits on growth, to Keynesian views and practises in the 1950s and 1960s, when public spending was conceived as a powerful tool to drive growth, and back to monetarist and neoclassical views about the destabilising inflationary pressures they

* Aristotle University of Thessaloniki Greece, Department of Economics, Thessaloniki 54124, Greece (katrak@econ.auth.gr, navgeris@econ.auth.gr).

The authors are indebted to Dr. D. Hatzinikolaou, Dr. C. Karfakis, Dr. G. Zarotiadis and Dr. T. Karasavvoglou for their helpful comments. Furhermore, they wish to thank the anonymous PEP referees for their valuable suggestions. 
induce. These shifts in economic thought have been reflected in various actions that were undertaken over the last decades, involving central bank independence all over the world, as well as the general trend towards fiscal austerity measures preached by institutions like the IMF and the WB to economies around the world. Economic unions have followed this trend with EU being the most obvious example. This trend was further enforced by monetarist economists who stretched the idea of the destabilising effect of the eventual monetisation of persistent deficits as well as more recent developments which pointed to the effects on expectations and the different implications of the same effects on the output and unemployment gaps that deficits may have. Consequently, it is a matter of major importance to thoroughly examine the existence of a possible causal link between fiscal imbalances and inflation.

Initially dynamic panel methods are used to investigate a group of countries for an adequately long time span. Secondly, this paper takes into account possible heterogeneity effects among countries by separately considering developing and developed countries. Furthermore, to ensure the robustness of the obtained results we include other conditioning variables, namely monetary expansion, trade openness, oil price changes and demand. Monetary expansion is incorporated as an explanatory variable to better illustrate the channels through which budget deficits may cause inflationary pressures. This approach adds a new element to the on-going debate about the monetarist argument since it sheds more light on the channels through which fiscal imbalances can be empirically proven to affect inflation. Theoretical claims that inflationary effects cannot be examined separately from other significant macroeconomic variables that affect the rate of change of prices are addressed by adding the other variables.

The rest of the paper is organised as follows. In Section 2, the theoretical background for the relationship between fiscal imbalances and inflation is examined while Section 3 builds upon the aforementioned theoretical background to derive a relationship that can be empirically tested. Section 4 describes the data that are used followed by Section 5 , which illustrates in detail the econometric techniques used, the results obtained and presents a discussion on the empirical findings. Finally Section 6 summarizes and concludes.

\section{Theoretical Background}

Hayek was the first to criticize Keynesian approaches on the issue of public spending which was advocated as a tool for growth. According to Hayek (1966) Keynes made the erroneous assumption that "no scarcity exists." Hayek suggested that growth is actually supply constrained and unemployment can be conceived as a short-term outcome of economic agents' mistaken expectations. Thus, any efforts to stimulate the economy via public spending would be doomed to have negative effects especially on inflation. Building on the same reasoning monetarist economists with Milton Friedman being the most prominent, used the natural or non-accelerating inflation rate of unemployment (NAIRU) to support the same view even though that was later criticized (Vickrey, 1998; Smithin, 1996). 
After the relative demise of the Hayekian scarcity principle and the NAIRU, the view of the intertemporal budget constraint for the government has emerged which linked monetary and fiscal policy in three policy regimes. ${ }^{1}$ These theories were the result of the trend towards an increased role of expectations in the formation of the LM curve. Three different policy regimes have been approached in the theoretical struggle to link fiscal imbalances and inflation.

In the first policy regime, fiscal policy is assumed to adjust to ensure that the government 's intertemporal budget is always in balance while monetary policy is free to set the nominal money stock or the nominal rate of interest. This is called a Ricardian regime where monetary policy is dominating fiscal policy (Sargent and Wallace, 1981; Leeper, 1991). Initially this model implied that in order to avoid inflationary pressures, monetary policy has to dominate fiscal policy. Later theoretical postulations, however, indicated that even in that case, inflation can be caused by the decisions about public spending (Walsh, 2003) through the effect on interest rates. (i.e. the Ricardian equivalence does not hold). ${ }^{2}$

The second policy regime is the one where the fiscal authorities exogenously determine their expenditure and taxes, thus being dominant over monetary targets (Sargent and Wallace, 1981; Rao Aiyagari and Gertler, 1985). Accordingly if the present discounted value of these taxes is not enough to cover all expenditures then seigniorage must adjust to ensure that the government's intertemporal budget constraint is satisfied. In this case the empirical difficulty ${ }^{3}$ to link deficits with the expansion of money supply was credited to the ability of the government to borrow and thus transfer the need to monetise, deeper in time (Sargent and Wallace, 1981). However, under persistent deficits seigniorage would eventually occur leading to inflation.

Finally, the third policy regime, which is the most recently developed, is known as the fiscal theory of the price level (FTPL). Its main proponents being Woodford (1995) and Cochrane (Cochrane, 2001) suggested that in the context of a non-Ricardian environment fiscal deficits will cause inflation. This happens because fiscal solvency is ensured automatically through changes in price level rather than by government's actions. This regime was, however, heavily criticised by Buiter (2002) and McCallum (1999; 2001; 2003) on the basis of its theoretical foundation.

1 Sargent and Wallace (1981) and Sargent (1987) clearly illustrate the importance of the budget constraint for the analysis of monetary topics.

2 A balanced budget increase in expenditures that raises the real interest rate (since more taxes reduce available savings), raises the nominal interest rate and decreases the demand for money, thus given an exogenous path of the nominal money supply, inflation will occur to decrease the real supply of money.

3 Friedman (1981) noted: "Put wartime periods aside, many other factors typically affect the rate of monetary growth, so that there is only the loosest relation in practise between monetary growth and deficits" while Brunner (1969) observes that there are occurrences of inflation without large budget deficits and very large changes in deficits with no visible effect on the broad behaviour of the economy and Meltzer (1976) extends that to even the case of hyperinflation periods using the example of Germany in the 1920s. 
Opposed to the aforementioned theories came two post Keynesian schools of thought which viewed the role of deficits in the economy totally differently. The monetary circuit approach as well as the neo-Chartalism monetary theory both criticised the mainstream monetary theory on the basis of the exogeneity of the monetary base that the latter accepted. Modern supporters of the monetary circuit approach (Graziani, 1989; Graziani, 2003; Bellofiore, Davanzati, and Realfonzo, 2000; Nell, 2002) propose that deficits should lead to inflation regardless of whether they are monetized or not by making a distinction between hard and credit money. ${ }^{4}$ Neo Chartalism proponents (Mitchell, 2009; Febrero, 2009; Wray, 2003) on the other hand argued for the endogeneity of money but traced its origins in public spending and deficits and implied that they are vital to sustained growth. They also pointed to the fallacy of condemning any suggested inflationary pressures that public spending and deficits might create.

\section{Deriving the Econometrical Expression}

Whether someone uses a simple equation of exchange or the accelerationist Philips Curve or the new Keynesian Phillips curve (NKPC), the result of fiscal activity on inflation is the same.

To illustrate how fiscal expansion can affect inflation employing the first method we consider the simple form of the equation of exchange:

$$
\mathrm{MV}=\mathrm{PQ}
$$

where $\mathrm{M}$ is the total amount of money in circulation in an economy

$\mathrm{V}$ is velocity of money, that is the average frequency with which a unit of money is spent

$\mathrm{P}$ is price level

$\mathrm{Q}$ is real expenditure

If we express the equation of exchange in terms of growth rates and considering, for matters of simplicity, $V$ as constant, ${ }^{5}$ then:

$$
\frac{\Delta P}{P}=\frac{\Delta M}{M}-\frac{\Delta Q}{Q}
$$

4 This is a direct critique against the argument of Sargent and Wallace (1982) about governments avoiding inflation due to lending.

5 Besides the weaknesses in the very nature of the term "monetary velocity" assuming a constant velocity of money in a dynamic analysis provides a good trade-off of simplicity versus robustness since the speed of money does not present a causal factor of prices. As Drewry (1968) puts it: "Increased velocity of circulation is not, in itself, even a contributing cause of higher commodity prices. It is not even a link in the chain of causation. Increased velocity of circulation and higher commodity prices are joint results of a change in the value of money in relation to the value of goods." Thus eliminating V from an equation whose purpose is to examine the causal relationship between public budget deficits and the change in the consumer price index does not create drawbacks. 
That is to say, if $V$ is constant, then the inflation rate would exactly equal the growth rate of the monetary base minus the growth of output.

Consequently, modelling deficit in line with the Hayekian and monetarist arguments we have:

$$
\mathrm{PBL}=(\mathrm{T}-\mathrm{G})=\Delta \mathrm{B}+\Delta \mathrm{Z}
$$

where PBL is the public budget balance, $\mathrm{G}$ represents the total public expenditure (including interest payments on public debt), T represents taxes and $\Delta \mathrm{B}$ is the change in the stock of government debt held by the public while $\Delta \mathrm{Z}$ is the change in the stock of government debt held by the central bank. The change in the stock of government debt, $\Delta \mathrm{Z}$, held by the central bank when positive (negative) represents a monetary expansion (contraction) can be equal or smaller than the total change in the monetary base as shown in equation (4):

$$
\Delta \mathrm{Z}=\mathrm{a} \Delta \mathrm{M} \quad \text { with } \alpha \leq 1
$$

By substituting (4) into (3), then solving for $\Delta \mathrm{M}$ and replacing the result into (2) we get equation (5):

$$
\frac{\Delta P}{P}=\frac{1}{a}\left(\frac{T-G}{M}-\frac{\Delta B}{M}\right)-\frac{\Delta Q}{Q}
$$

This means that inflation is positively affected by an increase in the public deficit and negatively affected by an increase in the amount of debt owned by the private sector as well as by an increase in output growth. In case $\Delta \mathrm{Q}$ is 0 , due to the scarcity suggestion (Hayek, 1966), and since $\Delta \mathrm{B}$ will eventually become 0 due to the argument of Sargent and Wallace (1981) then at that point inflation will be determined only by the term (T-G)/M, where T-G is the public budget balance.

Using the second method, namely the accelerationist Philips Curve suggests that inflation is an outcome of the unemployment gap and previous inflation rate as in (6):

$$
\frac{\Delta P}{P_{t}}=-\gamma\left(U_{t}-U_{t}^{*}\right)+\frac{\Delta P}{P_{t-1}}
$$

Thus inflation is negatively correlated with deviations of the unemployment rate $\mathrm{U}$ (which is affected by government spending) from its natural rate $\mathrm{U}^{*}$

Thirdly, the new Keynesian Phillips Curve suggests that inflation is a function of next period's expected inflation rate $E_{t} \frac{\Delta P}{P_{t+1}}$, the output gap and an additive disturbance $x_{t}$
as in (7):

$$
\frac{\Delta P}{P_{t}}=E_{t} \frac{\Delta P}{P_{t+1}}+\varphi\left(y_{t}-y_{t}^{*}\right)+x_{t}
$$

In this case, fiscal expansion affects all, expected inflation, the output gap and the additive disturbance and it is expected to have a quantitatively positive influence on inflation. 
From the above, it becomes clear that all three theoretical approaches reach the same conclusion, namely that fiscal expansion (contraction) increases (decreases) inflation. Thus an empirical investigation should be focused on testing whether $\theta$ (in equation (8) that follows) can be found to be negative and statistically significant:

$$
\frac{\Delta P}{P_{t}}=\Theta \text { GovBalance }_{t}
$$

where $\theta$ is the coefficient of change of inflation to an $1 \%$ increase of the government budget balance. If the postulations by the aforementioned theories are correct it should be found significant and negative.

\section{Data}

It is expected that the effects of budget deficits on inflation vary across countries with different characteristics, such as different levels of financial development, inflation rates, levels of openness and institutions. This fact implies the existence of significant heterogeneity in the composition of our data set. Furthermore, when testing long-run equilibrium relationships a sufficiently long and uninterrupted time series data set is needed. Additionally it is important to include variables from all possible channels (demand, supply, monetary, fiscal etc.) through which inflation is affected to eliminate missing variable bias.

The data set in this study satisfies all the aforementioned conditions. In the case of our panel regressions it comprises of 52 countries, 19 developed and 33 developing ${ }^{6,7}$ for which no less than 30 years of continuous annual observations on our variables exist, starting from 1970 till 2009.

The fiscal balance measure used is the nominal surplus of the central government as reported in the International Monetary Fund's (IMF) International Financial Statistics (IFS) which includes transfers and net interest payments and is measured on a cash basis. Besides being the only viable choice of deficit measurement for a large pool of countries, it is also the one that most previous studies on the topic use. ${ }^{8}$

As a measure of monetary expansion we use the broad money expansion rate provided by the same database (i.e. IFS). ${ }^{9}$ It has been argued in the past, and is now generally accepted, that the proper measure of monetary expansion that affects inflation is not

6 The classification of developed and developing economies is taken from IMF's World Economic Outlook.

7 A list of the selected countries is given in the Appendix.

8 This measure is subject to two limitations: firstly, it can be a misleading indicator of changes in real government debt (regardless of whether it is scaled by GDP or current money stock) in periods of hyperinflation; and secondly it fails to incorporate local governments, public enterprises, and central bank losses which play a significant role in inflationary episodes in some countries. However, such a broader measure does not exist for most countries for a sufficient time span.

9 This includes less liquid assets than currency in circulation such as transferable deposits, savings deposits, traveller's checks securities other than shares electronic money etc. (IMF 2000). 
currency in circulation and bank reserves but also less liquid but still easily transformed to currency assets (Seccareccia and Sood, 2000). As already noted in the literature review, the most common cause of inflation by neoclassical economists and monetarists is the eventual monetisation of the deficit. Sargent and Wallace (1981), illustrated in their equilibrium modelling process that persistent deficits (higher than growth rates) will eventually have to be monetized as the public's demand for government debt has a limit and the central bank will have to print money to buy government bonds. However, the effect of an expansion of the monetary base can be accompanied by a contraction of a higher measure of money due to, for instance, a possible reduction in credit available etc. For that purpose we use the broad money rate of change as the best count of money supply in the exchange equation (as noted in Part 3).

Inflation is proxied by the annual percentage change of the consumer price index also found in IMF's IFS databank.

For a supply variable our initial efforts were in gathering labour cost data. However, such data is only available for developed countries and very few developing ones. This would forbid a comparative analysis between the two groups of countries so we resort to using oil price changes to examine the effects of higher production costs. Oil price is a well-known source of inflationary pressures in the world economy since, when oil cost increases so do production costs and prices of goods follow leading to inflation. Data was collected from the International Energy Agency's (IEA) Energy Prices and Taxes database. Observations report import prices per barrel of crude oil for each country. For the few cases of countries that data was not available, the area average was used. Most studies in the past use a universal measure of the oil price thus excluding different country specific effects. By using the import prices we are able to not just incorporate a supply cost measure but also make it country specific by including other factors that might explain industrial costs in country.

As a demand side variable we use a measure of Demand. Observations on final demand are readily available in the AMECO database, but only for developed countries. Thus we constructed a demand measure adding private and public consumption and gross fixed capital formation. Data were taken from IMF's IFS database.

Following Catao and Terrones (2005), we include one control variable in our model, namely trade openness, measured by the sum of exports and imports over GDP. Data for trade openness come from IMF's IFS. Trade openness, as argued by Romer (1993) and Lane (1997), determines how monetary expansion affects inflation. First the weight of the home goods sector will be smaller in a more open economy implying that the effect of monetary expansion on domestic employment (which affects inflation) will be also smaller, and secondly the currency depreciation resulting from a monetary expansion will raise domestic inflation by more than in a closed economy. Hence, the more open the economy is the less time-inconsistent the monetary policy, implying a negative relationship between openness and inflation. 
Gaps in the data were filled, where available, from $\mathrm{IMF}^{\prime} \mathrm{s}$ World Economic Outlook and ECOFIN's AMECO ${ }^{10}$ database. The resulting data set comprises of a lightly unbalanced $^{11}$ panel of 1517 observations for a sample of 52 countries, including both developed and developing ones, over the period 1970-2009. So far to the knowledge of the writers, no such a wide range of inflation determinants has been included in empirical panel analyses.

Furthermore, as was mentioned previously, the panel is divided into two groups, developed and developing, in order to gain more insight accounting for heterogeneity among countries. Table 1, reports some of the main descriptive measures of the examined series, reporting averages of the relevant ratios by country groups and decade long sub-periods.

Table 1

Data Summary Statistics

\begin{tabular}{|c|c|c|c|c|c|c|}
\hline & $\begin{array}{l}\text { Annual } \\
\text { Inflation }\end{array}$ & $\begin{array}{c}\text { Fiscal } \\
\text { Balance } \\
\text { (T-G)/Y }\end{array}$ & Openness & $\begin{array}{c}\text { Oil price } \\
\text { (\% change) }\end{array}$ & $\begin{array}{l}\text { Broad Money } \\
\text { Growth Rate }\end{array}$ & $\begin{array}{l}\text { Demand } \\
\text { (\% change) }\end{array}$ \\
\hline \multicolumn{7}{|l|}{ All Countries } \\
\hline $1970-1979$ & 9.83 & -2.33 & 66.10 & 58.82 & 19.16 & 16.48 \\
\hline 1980-1989 & 11.78 & -3.84 & 73.99 & -2.27 & 16.03 & 14.50 \\
\hline 1990-1999 & 10.67 & -2.24 & 77.66 & 1.67 & 14.93 & 14.82 \\
\hline $2000-2009$ & 5.70 & -0.73 & 82.28 & 20.61 & 12.75 & 9.90 \\
\hline \multicolumn{7}{|c|}{ Developed Countries } \\
\hline $1970-1979$ & 10.21 & -2.73 & 66.39 & 60.20 & 15.29 & 15.16 \\
\hline 1980-1989 & 7.48 & -4.23 & 78.81 & -2.21 & 12.61 & 10.65 \\
\hline 1990-1999 & 3.34 & -2.38 & 75.73 & 0.52 & 8.34 & 6.40 \\
\hline $2000-2009$ & 2.12 & -0.19 & 88.87 & 18.98 & 7.29 & 4.36 \\
\hline \multicolumn{7}{|c|}{ Developing Countries } \\
\hline 1970-1979 & 10.46 & -2.06 & 66.68 & 57.84 & 21.82 & 17.31 \\
\hline 1980-1989 & 14.21 & -3.55 & 70.02 & -2.31 & 17.71 & 16.72 \\
\hline 1990-1999 & 14.85 & -2.18 & 77.78 & 2.24 & 18.50 & 19.57 \\
\hline $2000-2007$ & 7.60 & -1.02 & 78.78 & 21.47 & 15.64 & 13.38 \\
\hline
\end{tabular}

\section{Methodological Issues and Empirical Results}

The first step in panel data estimation is to determine the appropriate econometric specification, discriminating between developed and developing countries to gain more insight on the heterogeneity issue among them. Usually, the choice of the appropriate

10 AMECO is the annual macro-economic database of the European Commission's Directorate General for Economic and Financial Affairs. AMECO contains data for EU-27 and other OECD countries.

11 Gaps in data are not creating a selection bias. 
specification lies among the following three simple panel formulations, namely the pooled OLS, the Fixed Effects (FEM) and the Random Effects (REM) model.

We started by testing for omitted country and time specific effects by means of a Breusch and Pagan Lagrange Multiplier test. The results, reported in Table 2 below, reject the null hypothesis of absence of both time specific and country specific effects, at the $1 \%$ level, revealing that a pooled regression is inappropriate in our case.

We next tested whether a REM or a FEM specification seems to be the most appropriate using the Hausman test (1978). In order to conclude in favour of a REM specification as our model, the individual effects must not be correlated with the regressors. In case this assumption does not hold the REM will be inconsistently estimated and we have to choose the FEM. The results, reported in Table 2, suggest that we can reject the null at the $1 \%$ significance level except the case of developed countries where it cannot be rejected. Since the assumption of no correlation is violated in the other cases, we adopt the FEM as our primary estimation model for the panels of all countries and developing countries and the REM for developed countries.

We then performed diagnostic tests for heteroscedasticity and autocorrelation. Starting with the assumption of homoscedasticity we first apply an LR test. The results reject the null of homoscedasticity so the GLS estimation procedure seems more appropriate to account for this problem with the condition that no autocorrelation exists. ${ }^{12}$ Wooldridge (2002) derives a simple test for autocorrelation in panel-data models. ${ }^{13}$ The results of the test in our case indicate the existence of autocorrelation.

Table 2

\section{Model Specification Test Results}

\begin{tabular}{|l|c|c|c|c|}
\hline \multicolumn{1}{|c|}{ Group } & Pooled OLS & REM & FEM & Autocorelation test \\
\hline All Countries & $\begin{array}{c}\text { BP test } \\
\text { (p-values) }\end{array}$ & $\begin{array}{c}\text { Hausman test } \\
\text { (p-values) }\end{array}$ & $\begin{array}{c}\text { LR test } \\
\text { (p-values) }\end{array}$ & \\
\hline $\begin{array}{l}\text { Developed } \\
\text { Countries }\end{array}$ & $0.00^{* * *}$ & $0.035^{* * *}$ & $0.00^{* * *}$ & $0.00^{* * *}$ \\
\hline $\begin{array}{l}\text { Developing } \\
\text { Countries }\end{array}$ & $0.00^{* * *}$ & 0.98 & $0.00^{* * *}$ & $0.00^{* * *}$ \\
\hline
\end{tabular}

Notes:

_ * indicates significance at $10 \%$ level, ${ }^{* *}$ indicates significance at $5 \%$ level and ${ }^{* * *}$ indicates significance at $1 \%$ level.

- all cells contain p-values

12 The GLS method is based on the very crucial "no autocorrelation" assumption and in case of autocorrelation, the GLS or FGLS (which is used when the true variance of individual effects is not known) method does not produce the maximum likelihood estimates, so we cannot use the appropriate inference techniques.

13 Drukker (2003) provides simulation results showing that the test has good size and power properties in reasonably sized samples. 
To deal with the problem of autocorrelation, it is required to explore the possibility that the autocorrelation arises due to model miss-specification. To face this problem a new dynamic panel data model (DPDM), is specified by adding a lagged endogenous variable as follows:

$$
\operatorname{Inf}_{\mathrm{i}, \mathrm{t}}=\alpha_{\mathrm{t}}+\gamma \operatorname{Inf}_{\mathrm{i}, \mathrm{t}-\mathrm{1}}+\beta \operatorname{Sur}_{\mathrm{i}, \mathrm{t}}+\eta_{\mathrm{i}}+\mathrm{u}_{\mathrm{i}, \mathrm{t}}
$$

where Inf are the observations of inflation and Sur the observations for the public Surplus both denoted for county $i$ at time $t$.

The inclusion of a lagged dependent variable introduces a source of persistence over time, due to the correlation between the lagged regressor and the error term ui,t. Another problem is that, DPDMs are characterised by individual effects $\eta i$ caused by heterogeneity among the individuals. Thus, we use the GMM estimator which is known as the difference estimator and was proposed by Arellano and Bond (1991). The estimation method eliminates country and time specific effects ( $\eta$ i) by expressing Equation (9) in first differences as follows:

$$
\Delta \operatorname{Inf}_{\mathrm{i}, \mathrm{t}}=\gamma \Delta \operatorname{Inf}_{\mathrm{i}, \mathrm{t}-1}+\beta \Delta \operatorname{Def}_{\mathrm{i}, \mathrm{t}}+\Delta \mathrm{u}_{\mathrm{i}, \mathrm{t}}
$$

on the basis of the following standard moment condition:

$$
\mathrm{E}\left(\Delta \operatorname{Inf}_{\mathrm{i}, \mathrm{t}-\mathrm{s}} \Delta \mathrm{u}_{\mathrm{i}, \mathrm{t}}\right)=0, \text { for } \mathrm{t}=3, \ldots, \mathrm{N} \text { and } \mathrm{s} \geq 2 .
$$

However, there seems to be a problem with it since Blundell and Bond (1998) state that the GMM estimator obtained after first differencing has been found to have large finite sample bias and poor precision ${ }^{14}$. Consequently, they have proposed an extended, more efficient and more consistent generalized method of moments estimation (GMM) for DPDMs based on the following moment condition:

$$
\mathrm{E}\left[\operatorname{Inf}_{\mathrm{i}, \mathrm{t}-1}\left(\eta_{\mathrm{i}}+\mathrm{u}_{\mathrm{i}, \mathrm{t}}\right)\right]=0
$$

where $\Delta$ is the first difference operator.

Therefore, the extended GMM encompasses a regression equation in both differences and levels, each one with its specific set of instrumental variables. This type of system estimation method, not only improves the precision but also reduces the finite sample bias. The model assumes that the disturbances $\mathrm{u}_{\mathrm{i}, \mathrm{t}}$ are not serially correlated. If this is the case, there should be evidence of first order serial correlation in differenced residuals (i.e. $\Delta \mathrm{u}_{\mathrm{i}, \mathrm{t}}$ ), but no evidence of second order serial correlation (Doornik, Arellano and Bond, 2002). The above assumption is important because the consistency of the GMM estimators hinges upon the fact that $\mathrm{E}\left[\Delta \mathrm{u}_{\mathrm{i}, \mathrm{t}} \Delta \mathrm{u}_{\mathrm{i},-2}\right]=0$. Thus, testing the first-differenced residuals for autocorrelation up to second order is required. Additionally, by using the two steps GMM we get theoretically robust standard errors and subsequently we can

14 They attribute these problems to the weakness of the lagged levels of the series to provide instruments for the first difference. 
apply the Windmeijer (2005) correction in order to guarantee that the standard errors are not downward biased due to the relatively limited number of countries (Roodman, 2007). Furthermore, over-identifying restrictions tests are also reported based on the Hansen J statistic which is the minimized value of the two-step GMM criterion. This method uses lagged differences of the endogenous variables as instruments for equations in levels, in addition to lagged levels of inflation as instruments for equations in first differences.

The results of the aforementioned regression and tests are shown in Table 3:

Table 3

GMM System Results

\begin{tabular}{|l|c|c|c|c|c|c|c|c|c|}
\hline & $\begin{array}{c}\text { Inflation } \\
\text { Inertia }\end{array}$ & $\begin{array}{c}\text { Fiscal } \\
\text { Balance }\end{array}$ & Openness & $\begin{array}{c}\text { Oil Price } \\
\text { Change }\end{array}$ & $\begin{array}{c}\text { Broad } \\
\text { Money } \\
\text { Expansion }\end{array}$ & $\begin{array}{c}\text { Demand } \\
\text { Change }\end{array}$ & $\begin{array}{c}\text { AR(1)/ } \\
\text { AR(2) } \\
(\mathbf{p} \text { - values) }\end{array}$ & $\begin{array}{c}\text { Hansen } \\
(\mathbf{p} \text {-values })\end{array}$ & Obs. \\
\hline All Countries & $\begin{array}{c}0.19 \\
(0.04)^{* * *}\end{array}$ & $\begin{array}{c}-0.17 \\
(.03)^{* * *}\end{array}$ & $\begin{array}{c}-0.01 \\
(0.004)^{* * *}\end{array}$ & $\begin{array}{c}0.02 \\
(0.008)^{* * *}\end{array}$ & $\begin{array}{c}0.06 \\
(0.01)^{* * *}\end{array}$ & $\begin{array}{c}0.37 \\
(0.04)^{* * *}\end{array}$ & $\begin{array}{c}{[0.01]^{* * *}} \\
{[0.62]}\end{array}$ & {$[0.695]$} & 1517 \\
\hline $\begin{array}{l}\text { Developed } \\
\text { Countries }\end{array}$ & $\begin{array}{c}0.70 \\
(0.08)^{* * *}\end{array}$ & $\begin{array}{c}0.009 \\
(0.03)\end{array}$ & $\begin{array}{c}-0.005 \\
(0.001)^{* * *}\end{array}$ & $\begin{array}{c}0.02 \\
(0.004)^{* * *}\end{array}$ & $\begin{array}{c}0.04 \\
(0.022)^{*}\end{array}$ & $\begin{array}{c}0.30 \\
(0.06)^{* * *}\end{array}$ & $\begin{array}{c}{[0.06]^{*} /} \\
{[0.699]}\end{array}$ & {$[0.398]$} & 560 \\
\hline $\begin{array}{l}\text { Developing } \\
\text { Countries }\end{array}$ & $\begin{array}{c}0.18 \\
(0.06)^{* * *}\end{array}$ & $\begin{array}{c}-0.17 \\
(0.03)^{* * *}\end{array}$ & $\begin{array}{c}-0.02 \\
(0.01)^{* *}\end{array}$ & $\begin{array}{c}0.03 \\
(0.01)^{* *}\end{array}$ & $\begin{array}{c}0.05 \\
(0.02)^{* *}\end{array}$ & $\begin{array}{c}0.33 \\
(0.04)^{* * *}\end{array}$ & $\begin{array}{c}{[0.02]^{* *} /} \\
{[0.092]^{*}}\end{array}$ & {$[0.394]$} & 957 \\
\hline
\end{tabular}

Notes:

- * indicates significance at $10 \%$ level, ** indicates significance at $5 \%$ level and *** indicates significance at $1 \%$ level.

- Standard errors in parentheses,

- p-values in brackets

To summarise, the dynamic panel data GMM system estimator results (Table 3) indicate that the relationship between the fiscal balance and inflation, is negative and statistically significant only for developing countries. More specifically a $1 \%$ point deterioration on the government balance of developing countries raises the inflation rate by $0.17 \%$ while in the case of developed countries the coefficient suggests that the effect of an 1 percentage point increase in the budget deficit causes a $0.009 \%$ increase in inflation which is, however, statistically insignificant.

Looking at the additional variables that aim at providing robustness to the model we note that the coefficients on trade openness have the theoretically expected signs in all cases and are found significant for both developing and developed countries. However, the magnitudes of the coefficients differ between the two groups (-0.02 and -0.005 for developing and developed ones, respectively). The difference indicates that at lower levels of openness (developing economies) an economy experiences larger changes in inflation from a change in trade openness as opposed to economies with high trade openness percentages (developed economies). Thus findings seem to support the argument of Terra (1998) and Bleaney (1999), that the effects of trade openness on inflation are group specific. 
Oil price inflation is found significant both for developed countries and for developing countries as being expected and furthermore the coefficients between the two groups of countries are very similar ( 0.03 and 0.02$)$ indicating that oil prices affect both groups in the same way. However, this matter is outside the boundaries of the present endeavour and thus will not be further explored. ${ }^{15}$

Inflation inertia is found to be statistically significant in both cases in accordance to Chopra (1985), with a much higher coefficient for developed countries (0.7) in comparison to 0.18 for developing ones. The much lower volatility of inflation rates that are observed in developed countries can explain the aforementioned results as more of the previous year's inflation is carried over to the next one due to a more consistent inflation targeting strategy by their monetary institutions.

Furthermore, the inclusion of demand's annual rate of change provides homogenous results for both groups. A $1 \%$ change in demand generates $0.30 \%$ of inflation for developed countries and $0.33 \%$ for developingoues. It is important here to note that demand is the largest inflation determinant in both developing and developed countries.

On the other hand, monetary expansion seems to be significant (at the $10 \%$ and $5 \%$ confidence intervals) in determining inflation in developed and developing economies. As is often erroneously expected, budget deficits that cause inflation should do so by seigniorage mainly, so finding a causal relationship between inflation and deficits should imply the existence of a relationship between deficits and monetary expansion in the first stage and monetary expansion and inflation in the second. The findings of this study indicate that this might be more complicated in practise, deficits are not found to be significantly connected with inflation but monetary expansion is in the case of developed countries. Since fiscal imbalances do not statistically influence monetary expansion in auxiliary regressions we are led to conclude that the argument of Sargent and Wallace of the eventual monetisation of deficits does not hold.

As for developing countries, our results seem to agree with a number of Nordhausapproach studies that have elaborated on the link between monetary expansion and fiscal imbalances. Bates (1988) studies Zambia. McGillivray (2009) examines pre electoral campaigns in the Philippines while Durevall and Ndung'u (2001) report the case of Kenya. Krueger and Turan (1993) describe expenditure policy cycles around elections in Turkey in the 1950-1980 period. Calvo and Mendoza (1996) mention that the Mexican crisis partly resulted from the significant increase in the quasi-fiscal deficit (associated with the extension of credit, e.g. through development banks) before the elections in 1994. This also lays support to the argument that developing countries have curtailed their inflation rates thanks to the more "responsible" monetary policies undertaken with the guidance from international institutions like the IMF and the World Bank over the last decades.

Finally, the evidence (Table 3) on the relationship between fiscal imbalances and inflation seems to be puzzling, to say the least. In developed economies, there is no

15 See Le Blanc \& Chin (2004) for a further discussion of this topic. 
statistically significant evidence for the relationship between the two variables, while in developing economies the opposite happens. Catao and Terrones (2005) also find similar evidence in a study on the determinants of inflation. Our study once again seems to support the argument that the nature of the examined relationship may differ between different groups and even between different countries pointing to the fact that groups of countries have to be examined separately since a disproportionate weight of one group may bias the results. An $1 \%$ point change in the fiscal balance causes a $0.17 \%$ change in the rate of inflation, in the opposite direction in developing economies while the relationship is not statistically significant for developed countries.

Accordingly, it seems that there must be a set of characteristics that allow countries to manage their intertemporal budget constraint more efficiently than others and thus weaken inflationary pressures. Canzoneri et al. (2001), suggest that these are the following: a) well established institutions that curb fiscal profligacy, b) central banks that are committed to low inflation and c) deep financial markets. These three characteristics may be the reason why increases in fiscal deficits (or their reduction) do not increase (decrease) the rate of inflation. Coupled with the persistent deficits that are witnessed by almost all developed countries, we are led to conclude that governments do not have to monetise their debt eventually, as the argument of Sargent and Wallace would suggest. One explanation of that could be the possible endogeneity of money which is in line with the circuit approach (Seccareccia and Sood, 2000). Additionally, expectations also seem to not fuel inflation in the presence of fiscal imbalances in developed countries. Established institutions and financial development in advanced economies have achieved to reduce expectations of future inflation that could in turn cause inflation in times of negative fiscal balances and thus pressures in the general price level have been avoided.

\section{Conclusions}

This paper has attempted to examine the relationship between fiscal imbalances and inflation and to illustrate the differences of the underlying attributes in theory and practise by accounting for the implications of heterogeneity.

In the context of the empirical analysis, this study applied dynamic panel econometric methods on a pool of 52 countries over the period from 1970 to 2009. The results provided rather limited support for the theoretical postulations. More particularly even though the expected negative relationship between inflation and the public budget balance is empirically confirmed for developing countries, the same does not hold for the case of developed countries.

More specifically, for the group of developing countries, fiscal imbalances have been identified as the primary causal determinant of inflation as compared to inertia, demand side, supply side, monetary, and trade openness variables that have all been found statistically significant. 
For the group of developed countries, the empirical link between the two variables (i.e. inflation and budget deficits) cannot be verified. The arguments of monetarists do not seem to hold and this could be due to various factors. A commitment to fiscal profligacy in conjunction with the stability of their currencies might be significant in sustaining the price level. Secondly, the increased financial deepening and independent monetary authorities prevent fiscal imbalances to raise general prices. Thirdly, governments and institutions in advanced economies cultivate positive expectations in economic agents about the future stability of the economy, and thus avoid unnecessary expectationtriggered inflation pressures.

As a result, developing countries have to anticipate inflationary shocks after fiscal balance shocks have occurred. Besides that, fiscal imbalances seem to be the main explanatory factor of inflation as compared to the other macroeconomic variables.

A further important conclusion of this study is the fact that heterogeneity, if not accounted for, may lead to wrong conclusions. Both developed and developing countries should be examined separately and researchers should be very critical when grouping countries with heterogeneous characteristic in order to examine theoretical postulations.

\section{References:}

Arellano, M., Bond, S. (1991), "Some Tests of Specification for Panel Data: Monte Carlo Evidence and an Application to Employment Equations." The Review of Economic Studies 58 (2): p. 277.

Bates, R. H. (1988), Toward a Political Economy of Development: a Rational Choice Perspective. Vol. 14. Univ of California Pr.

Bellofiore, R., Davanzati, G. F., Realfonzo, R. (2000), "Marx inside the Circuit: Discipline Device, Wage Bargaining and Unemployment in a Sequential Monetary Economy." Review of Political Economy 12 (4): pp. 403-417.

Bleaney, M. (1999), "The Disappearing Openness-inflation Relationship: a Cross-country Analysis of Inflation Rates." IMF Working Paper No. 99/161.

Blundell, R., Bond, S. (1998), "Initial Conditions and Moment Restrictions in Dynamic Panel Data Models." Journal of Econometrics 87 (1): pp. 115-143.

Brunner, K. (1969), "The Drift into Persistent Inflation." Wharton Quarterly: pp. 23-36.

Buiter, W. H. (2002), "The Fiscal Theory of the Price Level: A Critique." The Economic Journal 112 (481): pp. 459-480.

Calvo, G. A., Mendoza, E. G. (1996), "Mexico's Balance-of-Payments Crisis: a Chronicle of a Death Foretold." Journal of International Economics 41 (3-4): pp. 235-264.

Canzoneri, M. B., Cumby, R. E., Diba, B. T. (2001), "Fiscal Discipline and Exchange Rate Systems." The Economic Journal 111 (474): pp. 667-690.

Catao, L. A. V., Terrones, M. E. (2005), "Fiscal Deficits and Inflation." Journal of Monetary Economics 52 (3): pp. 529-554.

Chopra, A. (1985), "The Speed of Adjustment of the Inflation Rate in Developing Countries: A Study of Inertia (Vitesse D'adjustement Du Taux D'inflation Dans Les Pays En Développement: Étude De l'inertie)(Velocidad De Ajuste De La Tasa De Inflación En Los Países En Desarrollo: Examen De La Inercia)." Staff Papers-International Monetary Fund: 693-733. 
Cochrane, J. H. (2001), "Long-Term Debt and Optimal Policy in the Fiscal Theory of the Price Level." Econometrica 69 (1): pp. 69-116.

Doornik, J. A., Arellano, M., Bond, S. (2002), "Panel Data Estimation Using DPD for Ox." DPD Package for Ox Manual.

Drewry, Jr. (1968), "Money, the Market, and the State." In 35-44. University of Georgia Press.

Drukker, D. M. (2003), "Testing for Serial Correlation in Linear Panel-data Models." Stata Journal 3 (2): pp. 168-177.

Durevall, D., Ndung'u, N. S. (2001), "A Dynamic Model of Inflation of Kenya, 1974-96." Journal of African Economies 10 (1): p. 92.

Febrero, E. (2009), "Three Difficulties with Neo-Chartalism." Journal of Post Keynesian Economics 31 (3): pp. 523-541.

Friedman, M. (1981), "Deficits and Inflation." Newsweek, February 23, 1981.

Graziani, A. (1989), "The Theory of the Monetary Circuit."

Graziani, A. (2003), The Monetary Theory of Production. Vol. 92. Cambridge Univ Pr.

Hausman, J. A. (1978), "Specification Tests in Econometrics." Econometrica: Journal of the Econometric Society: pp. 1251-1271.

Hayek, F. A. (1966), "Personal Recollections of Keynes and the 'Keynesian Revolution." Contra Keynes and Cambridge: Essays, Correspondence.

IMF (2000), "Monetary and Financial Statistics, Money Credit and Debt". International Monetary Fund.

Krueger, A. O., Turan, I. (1993), "The Politics and Economics of Turkish Policy Reform in the 1980s." In Political and Economic Interactions in Economic Policy Reform. Evidence from Eight Countries. Oxford: Blackwell.

Lane, P. R. (1997), "Inflation in Open Economies." Journal of International Economics 42 (3-4): pp. 327-347.

LeBlanc, M., Chinn, M. D. (2004), "Do High Oil Prices Presage Inflation? The Evidence from G-5 Countries." Business Economics 34: pp. 38-48.

Leeper, E. M. (1991), "Equilibria under Active' and Passive' Monetary and Fiscal Policies." Journal of Monetary Economics 27 (1): pp. 129-147.

McCallum, B. T. (1999), Recent Developments in Monetary Policy Analysis: The Roles of Theory and Evidence. National Bureau of Economic Research Cambridge, Mass., USA.

McCallum, B. T. (2001), Monetary Policy Analysis in Models Without Money. National Bureau of Economic Research Cambridge, Mass., USA.

McCallum, B. T. (2003), Is the Fiscal Theory of the Price Level Learnable? National Bureau of Economic Research Cambridge, Mass., USA.

McGillivray, M. (2009), "Aid, Economic Reform, and Public Sector Fiscal Behaviour in Developing Countries." Review of Development Economics 13 (3): pp. 526-542.

Meltzer, A. H. (1976), "Statement on Monetary Policy, June 24, 1976." US House of Representatives Committee on Banking, Currency, and Housing, Ending Inflation: The Next Steps. Washington, DC: Government Printing Office: pp. 178-180.

Mitchell, W. F. (2009), A Modern Monetary Perspective on the Crisis and a Reform Agenda. Centre of Full Employment and Equity, University of Newcastle.

Nell, E. J. (2002), "On Realizing Profits in Money." Review of Political Economy 14 (4): pp. 519-530.

Rao Aiyagari, S., Gertler, M. (1985), "The Backing of Government Bonds and Monetarism." Journal of Monetary Economics 16 (1): pp. 19-44.

Romer, D. (1993), "Openness and Inflation: Theory and Evidence." The Quarterly Journal of Economics 108 (4): p. 869.

Roodman, D. (2007), "How to Do Xtabond2: An Introduction to Difference and System GMM in Stata." 
Sargent, T. J. (1987), Dynamic Macroeconomic Theory. Harvard University Press.

Sargent, T. J., Wallace, N. (1981), "Some Unpleasant Monetarist Arithmetic." Federal Reserve Bank of Minneapolis Quarterly Review 5 (3): pp. 1-17.

Seccareccia, M., Sood, A. (2000), "Government Debt Monetization and Inflation: A Somewhat Jaundiced View." In The Economics of Public Spending: Debts, Deficits and Economic Performance, Cheltenham, UK: Edward Elgar Publishing Ltd: pp. 98-121.

Smithin, J. (1996), Macroeconomic Policy and the Future of Capitalism: The Revenge of the Rentiers and the Threat to Prosperity. UK: E. Elgar Publishing.

Terra, C. T. (1998), "Openness and Inflation: A New Assessment." The Quarterly Journal of Economics 113 (2): pp. 641-648.

Vickrey, W. (1998), "Fifteen Fatal Fallacies of Financial Fundamentalism: A Disquisition on Demandside Economics." Proceedings of the National Academy of Sciences 95 (3): p. 1340.

Walsh, C. E. (2003), Monetary Theory and Policy. MIT Press.

Windmeijer, F. (2005), "A Finite Sample Correction for the Variance of Linear Efficient Two-step GMM Estimators." Journal of Econometrics 126 (1): pp. 25-51.

Woodford, M. (1995), "Price-level Determinacy without Control of a Monetary Aggregate 1." In Carnegie-Rochester Conference Series on Public Policy, 43: pp.1-46.

Wooldridge, J. M. (2002), Econometric Analysis of Cross Section and Panel Data. The MIT Press.

Wray, L. R. (2003), "The Neo-Chartalist Approach to Money." In The State, the Market, and the Euro: Chartalism Versus Metallism in the Theory of Money: p. 89.

\section{APPENDIX:}

Table 5

List of Countries Used in the Empirical Investigation

\begin{tabular}{|l|l|l|l|l|l|}
\hline \multicolumn{3}{|c|}{ Developed Countries } & \multicolumn{3}{c|}{ Developing Countries } \\
\hline Belgium & Finland & France & Malaysia & Colombia & Venezuela \\
\hline Greece & Singapore & Italy & South Africa & Iran & Ecuador \\
\hline United Kingdom & United States & Germany & Burundi & Kenya & Nepal \\
\hline Japan & Netherlands & Spain & Costa Rica & Guatemala & Panama \\
\hline Sweden & Switzerland & Ireland & Rwanda & Tanzania & Thailand \\
\hline Korea & Australia & Cyprus & Honduras & Jordan & Zambia \\
\hline New Zealand & & & Bahamas & Barbados & Burkina Faso \\
\hline \multirow{3}{*}{} & & & Swaziland & China & Dominican R. \\
\cline { 4 - 6 } & & Fiji & Guyana & Haiti \\
\cline { 4 - 6 } & & Kuwait & Malawi & Mali \\
\cline { 4 - 6 } & & Paraguay & $\begin{array}{l}\text { Papua New } \\
\text { Guinea }\end{array}$ & Sierra Leone \\
\hline
\end{tabular}

